\title{
Nitrogen efficiency in hydroponic chicory
}

\section{Arthur Bernardes Cecílio Filho, Roberto Luciano Coelho, Tatiana Pagan Loeiro da Cunha \& Et Miguel Urrestarazu}

To cite this article: Arthur Bernardes Cecílio Filho, Roberto Luciano Coelho, Tatiana Pagan Loeiro da Cunha \& Et Miguel Urrestarazu (2017) Nitrogen efficiency in hydroponic chicory, Journal of Plant Nutrition, 40:18, 2532-2539, DOI: 10.1080/01904167.2017.1380818

To link to this article: https://doi.org/10.1080/01904167.2017.1380818

Accepted author version posted online: 19

Sep 2017.

Published online: 23 Oct 2017.

Submit your article to this journal

山ll Article views: 128

View Crossmark data $־$ 


\title{
Nitrogen efficiency in hydroponic chicory
}

\author{
Arthur Bernardes Cecílio Filho (iD ${ }^{a}$, Roberto Luciano Coelho ${ }^{a}$, \\ Tatiana Pagan Loeiro da Cunha (iD ${ }^{a}$, and Et Miguel Urrestarazu (iD ${ }^{b}$ \\ aDepartamento de Produção Vegetal, Faculdade de Ciências Agrárias e Veterinárias, Campus de Jaboticabal, UNESP -

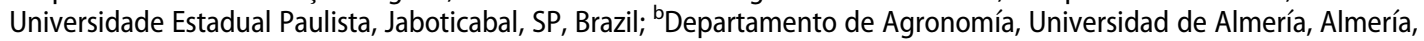 \\ Spain
}

\begin{abstract}
An experiment was conducted to develop a model of vegetative growth based on the nitrate concentrations in nutrient solutions using the nutrient film technique and to determine the best cultivar for each concentration. The chicory cultivars ("Pão de Açúcar," "Folha Larga," "Precoce de Trieste" and "Catalonha") and the subplots corresponded to different nitrate concentrations $\left(6.68,10.0,13.32\right.$ and $\left.16.64 \mathrm{mmol} \mathrm{L}^{-1}\right)$. There was an interaction between the evaluated factors, such that there was no similarity in the response of the chicory cultivars to the $\mathrm{N}$ concentrations in the nutrient solution. The most productive chicory cultivar was "Pão de Açúcar," which exhibited $10.5 \%$ higher productivity than the average, and the least productive was "Folha Larga," which showed approximately $8.5 \%$ lower productivity than the average.
\end{abstract}

\section{ARTICLE HISTORY}

Received 15 March 2015

Accepted 30 January 2017

\section{KEYWORDS}

cichorium intybus; growth model; hydroponic systems; mineral nutrition

\section{Introduction}

Hydroponic growing represents an alternative to conventional farming, with benefits for consumers, producers and the environment. Some of these advantages are allowing cultivation in small areas, reduction of the crop cycle and production throughout the year, achieving the best prices and reducing the consumption of water, of agricultural inputs and manual labor (Paulus, Dourado Neto, and Paulus 2012; Santos et al. 2013). Moreover, this system allows climatic conditions to be controlled and nutrients with appropriate concentrations to be provided for the growth and development of plants, increasing the productivity and quality of the final product (López-Pozos et al. 2011; Genuncio et al. 2012).

In Brazil, lettuce (Lactuca sativa L.) is the vegetable that is using hydroponics, following the nutrient film technique (NFT) method. On the other hand, chicory (Cichorium intybus L.) is becoming more popular among consumers due to its nutritional and medicinal properties, including high levels of protein, fiber, calcium, iron and vitamin A (Rasmussen, Klausen, and Ekstrand 2014). Another relevant point in favor of chicory is related to the commercial value of this vegetable, whose price remains stable throughout the year at a higher average than that of lettuce (Cavarianni et al. 2005; Santos et al. 2013).

Because of its similarity to lettuce in terms of the required hydroponic facilities, chicory is becoming a good alternative for the producer in the period of low economic profitability of lettuce, occurs in the months from April to October (Cavarianni et al. 2005; Maboko and Du Ploy 2009). However, information about the growth of chicory using hydroponics and NFT and when to cultivate it is not available to producers, and the information available for lettuce is used instead (Cecílio Filho et al. 2015).

CONTACT Et Miguel Urrestarazu mgavilan@ual.es E Departamento de Agronomía, Universidad de Almería, La Cañada de San Urbano s/n, C.P. 04120, Almería, Spain. 
As a leafy vegetable, chicory is very responsive to nitrogen $(\mathrm{N})$ application, and nutritional management is extremely important for the success of its cultivation. Hence, specific information about the best of $\mathrm{N}$ to be applied must be made available because inappropriate handling of $\mathrm{N}$ can cause nutritional disorders (Urrestarazu et al. 2008; Steiner et al. 2010; Colla et al. 2011). Under N deficiency, even for a short period, growth is slowed, and malformations are induced in plants, resulting in yellowish leaves and directly affecting physiological and morphological mechanisms (Sakai et al. 2011; Mou et al. 2013; Kerbiriou et al. 2014). When $\mathrm{N}$ is present in excess, it enables excessive uptake of the element with negative effects on the quality of vegetables, such as nitrate accumulation in plants (Sakai et al. 2011). The consumption of vegetables with high nitrate levels can cause harm to human health, including the formation of nitrosamines (carcinogenic) (Urrestarazu et al. 1998; Pôrto et al. 2012).

In one of the few research papers addressing the growth of chicory using hydroponics, Godoi et al. (2007) evaluated two cultivars ("Pão-de-açúcar" and "Amarelo") and five concentrations of N (11, 16, 21,26 and $31 \mathrm{mmol} \mathrm{L}^{-1}$ ) and revealed interactions between factors. A concentration of $16 \mathrm{mmol} \mathrm{L}^{-1}$ $\mathrm{N}$ maximized the fresh mass, whereas higher concentrations $\left(>31 \mathrm{mmol} \mathrm{L}^{-1}\right)$ caused a reduction of this parameter, by approximately $8.3 \%$ in the "Amarelo" cultivar and $11.8 \%$ in the "Pão de Açúcar" cultivar.

The aim of this study was to develop a model of vegetative growth on the basis of nitrate concentrations in nutrient solutions under cultivation via NFT and to determine the best cultivar for each concentration.

\section{Materials and methods}

The experiment was carried out from 16 September 2010 to 10 November 2010 in Jaboticabal-SP, Brazil $\left(21^{\circ} 15^{\prime} 22^{\prime \prime} \mathrm{S}, 48^{\circ} 18^{\prime} 58^{\prime \prime} \mathrm{W}\right.$ and average altitude of $\left.575 \mathrm{~m}\right)$ using hydroponics, with an NFT system, in a greenhouse.

A randomized complete block design was used, with four replications. Four nitrate concentrations $\left(6.68,10.0,13.32\right.$ and $\left.16.64 \mathrm{mmol} \mathrm{L}^{-1}\right)$ in the nutrient solution (plots) and four cultivars of chicory ("Pão de Açúcar," "Catalonha," "Precoce de Trieste" and "Folha Larga") (subplots) were evaluated. The experimental unit consisted of 50 plants $\left(1.125 \mathrm{~m}^{2}\right)$.

The "Pão de Açúcar" cultivar requires 80 to 100 days to complete its cycle, its leaves are cabbage-like and bright green in color, with a height of 20 to $30 \mathrm{~cm}$, forming the head. "Catalonha" completes its cycle in 50 to 70 days and exhibits flat sheets and jagged edges that are green in color, with a height of 18 to $25 \mathrm{~cm}$. "Precoce de Trieste" is characterized by broad leaves with a bright green color. "Folha Larga" presents a cycle of 50 to 70 days and produces flat sheets that are bright green in color with a height between 15 and $20 \mathrm{~cm}$. These four varieties are still cultivated by producers.

Sowing was carried out in phenolic foam plates with cells of $2.0 \times 2.0 \times 2.0 \mathrm{~cm}$ that had previously been washed in running water for $5 \mathrm{~min}$. Two seeds per cell were placed at a depth of $0.5 \mathrm{~cm}$, leaving one plant per cell after thinning. When the seedlings showed a height of approximately $3.0 \mathrm{~cm}$ (10 days after sowing - DAS), they were transferred to a pool (floating system), with a $3.0-\mathrm{cm}$ layer of a nutrient solution containing the following macronutrient concentrations (in mmol): 0.23 phosphorus (P); 1.69 potassium $(\mathrm{K}) ; 0.96$ calcium $(\mathrm{Ca}) ; 0.26$ magnesium $(\mathrm{Mg}) ; 0.19$ sulfur $(\mathrm{S})$ and the following micronutrient concentrations (in $\left.\mathrm{mg} \mathrm{L}^{-1}\right)$ : 0.06 boron (B); 0.008 copper $(\mathrm{Cu}) ; 0.11$ manganese $(\mathrm{Mn})$; 0.02 molybdenum (Mo); 0.03 zinc ( $\mathrm{Zn}) ; 1.67$ iron (Fe). At this stage, $3.54 \mathrm{mmol} \mathrm{L} \mathrm{m}^{-1} \mathrm{~N}$ was used.

At 17 DAS, when the seedlings presented a height of $8.5 \mathrm{~cm}$ and three leaves, they were transplanted to cultivation channels made of PVC pipes cut longitudinally, with a diameter of $10 \mathrm{~cm}$, arranged on easels $1.20 \mathrm{~m}$ tall in the highest part of the stand, with a declivity of $3 \%$. The channels were covered with expanded polystyrene plates $1.5 \mathrm{~cm}$ in thickness with holes $3.0 \mathrm{~cm}$ in diameter. The spacing between rows was $15.0 \mathrm{~cm}$ (center to center of channels) with $15.0 \mathrm{~cm}$ between plants (within the channels).

The nutrient solutions were based on the proposals of Sonneveld and Straver (1994) and Carrasco and Izquierdo (1996) regarding macro and micronutrients. The concentration of ammonium $\left(\mathrm{NH}_{4}{ }^{+}\right)$ ions was set at $15 \%$ of the total nitrogen in each nutrient solution. Nutrient solutions with 
concentrations of $6.82,10.00,13.32$ and $16.64 \mathrm{mmol} \mathrm{L}^{-1}$ nitrate $\left({\mathrm{N}-\mathrm{NO}_{3}}^{-}\right)$showed electrical conductivities of 2.0, 2.1, 2.3 and $2.3 \mathrm{dS} \mathrm{m}^{-1}$, respectively. The $\mathrm{pH}$ levels of the nutrient solutions were monitored and maintained between 5.5 and 6.5 using $6 \mathrm{~N}$ sulfuric acid.

The electrical conductivity was maintained at between 90 and $100 \%$ of each treatment's initial level by adding water or a stock solution of the same concentration as the treatment's initial nutrient solution. Every 7 days, the solution was exchanged. The reservoir provided a ratio of $1.25 \mathrm{~L}$ of solution per plant and the flow rate of the nutrient solution in the cultivation channels was $1.7 \mathrm{~L}$ per minute.

The circulation of the nutrient solution was controlled by a timer set such that there was intermittent movement from 6 to $11 \mathrm{hrs}$ and from 17 to $19 \mathrm{hrs}$, with $10^{\prime}$ of movement and $20^{\prime}$ of rest, and from 11 to 17 hrs with $10^{\prime}$ of movement and $10^{\prime}$ of rest. At night, circulation was carried out twice, for 10 min each at 22.00 and $2.00 \mathrm{hrs}$.

Harvesting was carried out at 48 DAS, by collecting eight plants per subplot for evaluation. The following parameters were determined: plant height $(\mathrm{PH})$, as the length of the largest leaf from the top of the crop channel; shoot fresh mass (SFM), measured from 6 to $7 \mathrm{AM}$, weighing the leaves cut at $3.0 \mathrm{~cm}$ from the plant's lap, and shoot dry mass (SDM) and root dry mass (RDM), using material dried in a greenhouse with circulation and forced air renewal at $65^{\circ} \mathrm{C}$ for $96 \mathrm{hrs}$.

The data were subjected to analysis of variance with the $F$ test and polynomial regression for the nitrate doses and among cultivars. To develop this model, the mean values obtained for each cultivar were used. A Tukey test was used under $P<.05$.

\section{Results and discussion}

An effect of the cultivars on $\mathrm{pH}$ was observed (Tukey $<.05$ ), with "Catalonha" exhibiting the greatest height $(40.2 \mathrm{~cm})$, followed by "Folha Larga" $(36.7 \mathrm{~cm})$, "Pão de Açúcar" $(33.8 \mathrm{~cm})$ and "Precoce de Trieste" $(30.6 \mathrm{~cm})$. This result can be explained by the fact that "Catalonha" does not form a head, instead developing long and narrow leaves. On the other hand, "Pão de Açúcar" is characterized by forming a large compact head, but with a lower height (Santos et al. 2013). When studying the same cultivars in greenhouses, but planted in soil, Novo, Trani, and Minami (2003) also observed a greater height in "Catalonha" in relation to the others.

For the SFM, an interaction between the factors was observed. All of the chicory cultivars responded positively to the effect of nitrate. With the exception of "Catalonha," the observed responses fit a quadratic curve ( $R^{2}$ greater than 0.86), similar to the findings of Ulrich (1952) and Bennett (1993).

The maximum SFM for "Pão de Açúcar," of $121.5 \mathrm{~g} \mathrm{plant}^{-1}$, was obtained using $11.05 \mathrm{mmol} \mathrm{L}{ }^{-1}$ nitrate in the nutrient solution. This concentration was lower than that reported by Godoi et al. (2007), who obtained maximum productivity of chicory using $16 \mathrm{mmol} \mathrm{L}^{-1} \mathrm{~N}$ with $13.6 \mathrm{mmol} \mathrm{L}$ as nitrate. "Catalonha," "Folha Larga" and "Precoce de Trieste" presented similar SFM values of 98.1, 95.1 and $97.5 \mathrm{~g} \mathrm{plant}^{-1}$, which were obtained using $16.64,11.64$ and $12.44 \mathrm{mmol} \mathrm{L}^{-1}$ nitrate, respectively (Figure 1).

With the exception of "Catalonha," which showed the maximum SFM under the highest evaluated concentration of nitrate, in the other three cultivars, concentrations of nitrate higher than $13 \mathrm{mmol}$ $\mathrm{L}^{-1}$ caused a suppression of SFM accumulation, probably due to reaching toxic concentrations (Urrestarazu et al. 1998; Chiloane et al. 2012). In "Pão de Açúcar," the SFM obtained when using $16.64 \mathrm{mmol} \mathrm{L}^{-1}$ nitrate was lower than that measured at the lowest concentration $\left(6.68 \mathrm{mmol} \mathrm{L}^{-1}\right)$. In lettuce cultivation, the maximum yield is obtained with concentrations below that recommended by Sonneveld and Straver (1994) and which was $19 \mathrm{mmol} \mathrm{L}^{-1}$ nitrate.

Under the adopted spacing of the plants, the maximum SFM for "Pão de Açúcar" provided productivity of $5.4 \mathrm{~kg} \mathrm{~m}^{-2}$, which was approximately $20 \%$ higher than the highest productivities obtained in "Catalonha," "Folha Larga" and "Precoce de Trieste." Similarly, Novo, Trani, and Minami (2003) observed higher productivity with "Pão de Açúcar" $\left(5.5 \mathrm{~kg} \mathrm{~m}^{-2}\right)$ than with "Folha Larga" $\left(4.3 \mathrm{~kg} \mathrm{~m}^{-2}\right)$ or "Catalonha" ( $\left.4.3 \mathrm{~kg} \mathrm{~m}^{-2}\right)$. The better performance of "Pão de Açúcar" can be attributed to the greater number of leaves forming its head, unlike the other cultivars, which present fewer, loose leaves that do not form a head (Godoi et al. 2007; Santos et al. 2013). 


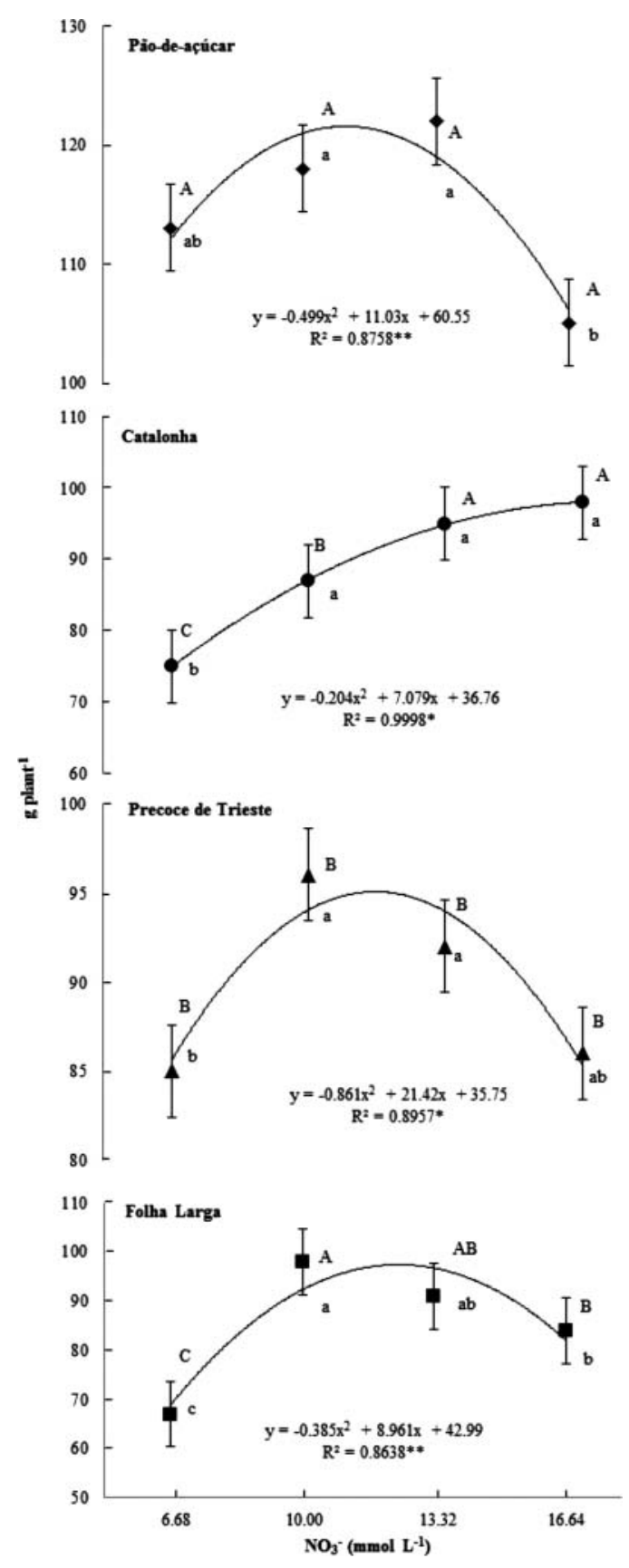

Figure 1. Shoot fresh mass (SFM) of chicory cultivars grown using hydroponics-NFT. Uppercase letters indicate comparisons of the yields between cultivars at each concentration of nitrate and lowercase letters indicate comparisons of the concentrations of nitrate in the nutrient solution for each cultivar.

The maximum production of dry mass (SDM) occurred at different concentrations of nitrate in the nutrient solution for each cultivar as observed for SFM. Maximum SDM production in "Pão de Açúcar" (6.6 g plant $\left.{ }^{-1}\right)$, "Catalonha" (5.8 g plant $\left.^{-1}\right)$, "Precoce de Trieste" (5.8 g plant $\left.{ }^{-1}\right)$ and "Folha Larga" (5.8 g plant $^{-1}$ ) was obtained at nitrate concentrations of $11.39,11.42,9.79$ and $11.98 \mathrm{mmol} \mathrm{L}^{-1}$, respectively (Figure 2).

In contrast to the findings for SFM, the superiority of "Pão de Açúcar" was not as important, showing no difference from "Catalonha" and "Precoce de Trieste" under some of the tested nitrate concentrations 


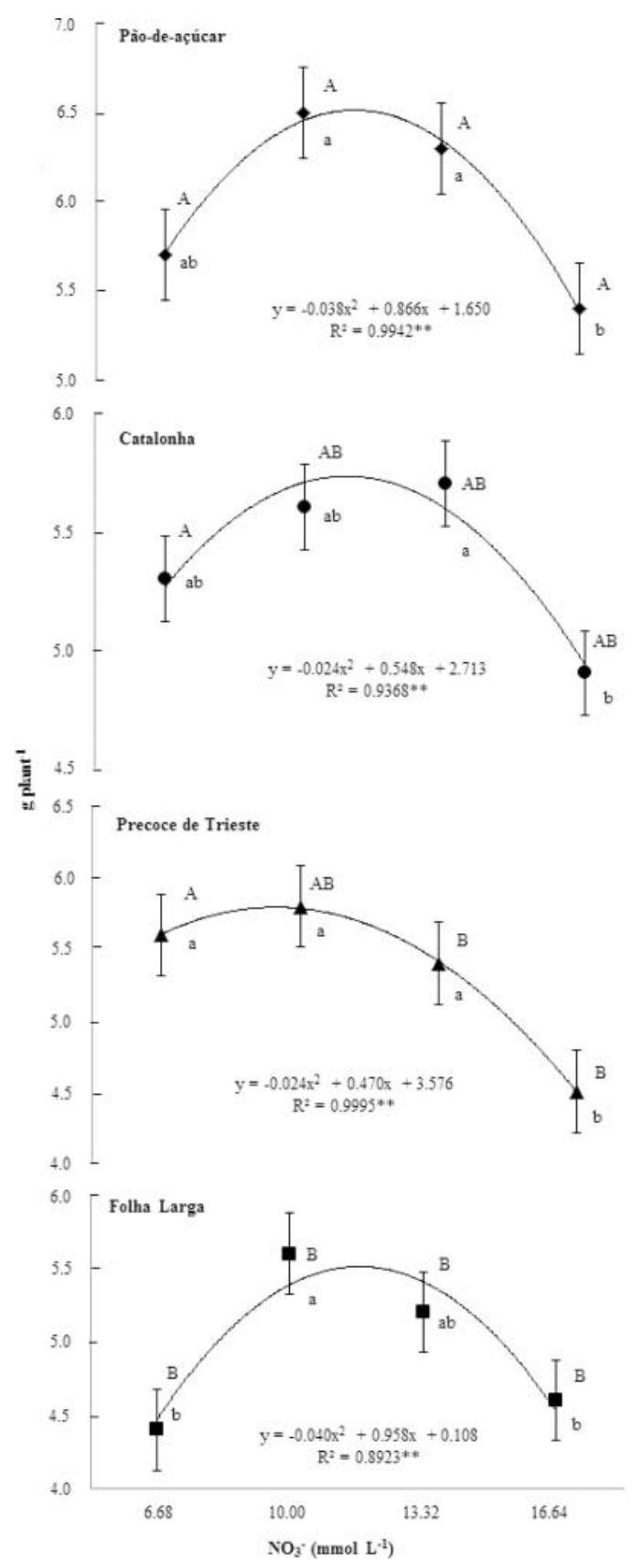

Figure 2. Shoot dry mass of chicory cultivars grown using hydroponics-NFT. Uppercase letters indicate comparisons of the average values for the cultivars at each nitrate concentration and lowercase letters indicate comparisons of the concentrations of nitrate in the nutrient solution for each cultivar.

in the nutrient solution. For "Pão de Açúcar" and "Precoce de Trieste," the lowest concentration of nitrate used did not differ from the highest concentrations of 10.00 and $13.32 \mathrm{mmol} \mathrm{L}^{-1}$ nitrate and was greater compared with the concentration of $16 \mathrm{mmol} \mathrm{L}^{-1}$ nitrate. For "Catalonha" and "Folha Larga," concentrations of 11.42 and $12.00 \mathrm{mmol} \mathrm{L}^{-1}$ were sufficient to obtain maximum productivity. In the maximum concentration of nitrate, all of the cultivars showed a suppression of SDM (Figure 2).

The nitrate concentrations required to maximize the production of SFM and SDM were similar for "Pão de Açúcar" (11.05 and $11.39 \mathrm{mmol} \mathrm{L}^{-1}$ ) and "Folha Larga" (11.64 and $11.98 \mathrm{mmol} \mathrm{L}^{-1}$ ), whereas 


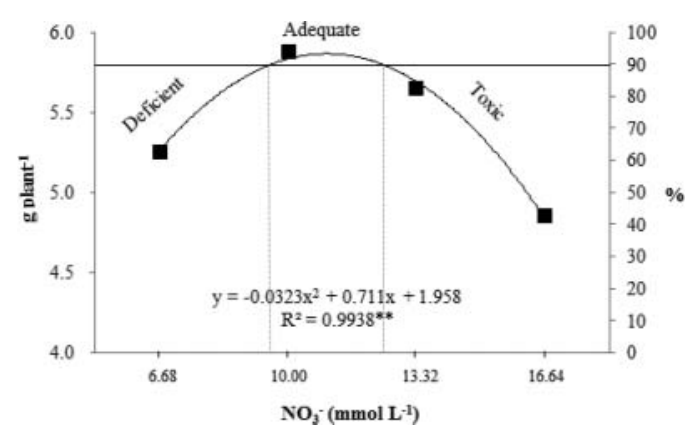

Figure 3. Curve model proposed for the nitrate concentrations in the nutrient solution for chicory grown using NFT.

for "Catalonha" (16.64 and $11.42 \mathrm{mmol} \mathrm{L}^{-1}$ ) and "Precoce de Trieste" (12.44 and $\left.9.79 \mathrm{mmol} \mathrm{L}^{-1}\right)$, they were distinct.

"Precoce de Trieste" was less responsive to increase in the nitrate concentration in the nutrient solution and therefore exhibited the lowest accumulation of SDM. In general, "Pão de Açúcar" was superior in terms of SFM and SDM, which can be explained by the genetic differences in the cultivars. "Pão de Açúcar" produces large, broad leaves, forming an elongated, compact, massive head and the whole plant can be commercialized. In contrast, the other cultivars do not form a head, and their leaves are cut $3 \mathrm{~cm}$ above the plant's lap and marketed in packs of $0.5 \mathrm{~kg}$ (Santos et al. 2013).

In accord with the obtained results, an equation was adjusted for nitrate concentrations in chicory. According to this model, to obtain $90 \%$ of maximum productivity, the required nitrate concentrations are in the range of 9.5 to $12.5 \mathrm{mmol} \mathrm{L}^{-1}$. In most cases, lower levels $\left(<9.5 \mathrm{mmol} \mathrm{L}^{-1}\right)$ are insufficient to achieve proper development of the plants, whereas levels higher than $12.5 \mathrm{mmol} \mathrm{L}^{-1}$ are toxic (Figure 3).

The production of RDM in "Pão de Açúcar" and "Precoce de Trieste" reached a maximum at concentrations of 12.17 and $10.53 \mathrm{mmol} \mathrm{L}^{-1}$ nitrate in the nutrient solution yielding an RDM of 1.2 and 1.6 g plant $^{-1}$, respectively. "Catalonha" and "Folha Larga" exhibited decreasing production as the nitrate concentration in the nutrient solution was increased, yielding maximum RDM values of 1.9 and $1.6 \mathrm{~g} \mathrm{plant}^{-1}$ under $6.64 \mathrm{mmol} \mathrm{L}^{-1}$ nitrate (Table 1).

With the exception of "Catalonha," the highest concentration $\left(16.64 \mathrm{mmol} \mathrm{L}^{-1}\right)$ resulted in a lower RDM in the tested cultivars (Table 1). The results obtained regarding the RDM of the chicory cultivars in this study differ from the findings of Pôrto et al. (2012). These authors observed a linear increase in $\mathrm{RDM}$ in "Elba" lettuce with increasing nitrate concentrations $\left(11,13,15,17,19\right.$ and $21 \mathrm{mmol} \mathrm{L}^{-1}$ ) using hydroponics.

In contrast to what was observed for SFM and SDM, the cultivar that generally showed the highest DMR was "Catalonha," though it did not differ from some of the other cultivars under certain concentrations. "Pão de Açúcar," which exhibited the highest SFM and SDM, was the cultivar with the lowest

Table 1. Root dry mass (RDM) of chicory cultivars (Cichorium intybus L.) on the basis of the nitrate concentration in the nutrient solution.

\begin{tabular}{|c|c|c|c|c|}
\hline \multirow[b]{2}{*}{$\mathrm{N}^{-\mathrm{NO}_{3}}{ }^{-}$} & \multicolumn{4}{|c|}{ RDM (g plant ${ }^{-1}$ ) } \\
\hline & "Pão de Açúcar" & "Catalonha" & "Precoce de Trieste" & "Folha Larga" \\
\hline 6.68 & $0.97^{\mathrm{Ca}}$ & $1.97^{\mathrm{Aa}}$ & $1.38^{\mathrm{Ba}}$ & $1.67^{\mathrm{ABa}}$ \\
\hline 10.00 & $1.10^{\mathrm{Ba}}$ & $1.51^{\mathrm{Ab}}$ & $1.61^{\mathrm{Aa}}$ & $1.48^{\mathrm{Aa}}$ \\
\hline 13.32 & $1.01^{\mathrm{Ba}}$ & $1.38^{\mathrm{Ab}}$ & $1.47^{\mathrm{Aa}}$ & $1.47^{\mathrm{Aa}}$ \\
\hline 16.64 & $0.85^{\mathrm{Ba}}$ & $1.57^{\text {Aab }}$ & $0.94^{\mathrm{Bb}}$ & $1.40^{\mathrm{Aa}}$ \\
\hline
\end{tabular}

Uppercase letters in the same row indicate significant differences between cultivars at the same nitrate concentration, while lowercase letters within the same column indicate significant differences between the four nitrate concentrations for the same cultivar $(P<.05$, according to Tukey's test). 
DMR (Table 1). This result explains the lack of a correlation of SDM and SFM with DMR, which can be attributed to the high availability of water and nutrients in the hydroponic environment, resulting in continued growth of the root system to meet the increased growth of shoots favored by higher nitrogen concentrations (Urrestarazu et al. 1998; Fallovo et al. 2009).

\section{Conclusions}

The chicory cultivars "Pão de Açúcar," "Folha Larga," "Catalonha" and "Precoce de Trieste" responded differently to increases in the nitrate concentration in the nutrient solution.

Maximum SHM yields were obtained in "Pão de Açúcar," "Folha Larga," "Catalonha" and "Precoce de Trieste" using 10.93, 12.81, 16.69 and $11.72 \mathrm{mg} \mathrm{L}^{-1} \mathrm{~N}$, respectively.

"Pão de Açúcar" was more productive than the other cultivars, in terms of both the shoot fresh or dry masses.

A vegetative growth model based on the nitrate concentrations in the nutrient solutions was developed, establishing that maximum growth for increasing the yield of chicory is achieved using between 9.50 and $12.50 \mathrm{mmol} \mathrm{L}^{-1}$ nitrate.

\section{ORCID}

Arthur Bernardes Cecílio Filho iD http://orcid.org/0000-0002-6706-5496

Tatiana Pagan Loeiro da Cunha iD http://orcid.org/0000-0002-3096-608X

Et Miguel Urrestarazu (iD) http://orcid.org/0000-0003-4340-2184

\section{References}

Benett, W. F. 1993. Nutrient deficiencies \& toxicities in crop plants. St. Paul, Minnesota, USA: APS Press, The American Phytopathological Society.

Carrasco, G., and J. Izquierdo. 1996. La empresa hidropónica de mediana escala: la técnica de la solución nutritiva recirculante ("NFT"). Talca, Chile: Editorial Universidad de Talca.

Cavarianni, R. L., A. B. Cecílio Filho, R. L. Coelho, and J. O. Cazetta. 2005. Teor de nitrato em cultivares de almeirão, cultivados em hidroponia, em função do horário de colheita. Científica 33:50-6.

Cecílio Filho, A. B., J. W. M. Cortez, D. Sordi, and M. Urrestarazu. 2015. Common chicory performance as influenced by iron concentration in the nutrient solution. Journal of Plant Nutrition 38 (10):1489-1494.

Chilone, T. S. 2012. Effect of nutrient concentration and growing seasons on growth, yield and quality of leafy lettuce (Lactuca sativa L.) in a hydroponic system. PhD thesis, University of Pretoria, Pretoria.

Colla, G., Y. Rouphael, C. Mirabelli, and M. Cardarelli. 2011. Nitrogen-use efficiency traits of mini-watermelon in response to grafting and nitrogen-fertilization doses. Journal of Plant Nutrition and Soil Science 174:933-41.

Fallovo, C., Y. Rouphael, E. Rea, A. Battistelli, and G. Colla. 2009. Nutrient solution concentration and growing season affect yield and quality of Lactuca sativa L. var. acephala in floating raft culture. Journal of the Science of Food and Agriculture 89:1682-9.

Genuncio, G. C., M. Gomes, A. C. Ferrari, N. Majerowicz, and E. Zonta. 2012. Hydroponic lettuce production in different concentrations and flow rates of nutrient solution. Horticultura Brasileira 30:526-30.

Godoi, R. S., J. L. Andriolo, J. C. C. Madalóz, D. I. Janisch, and C. A. P. Barros. 2007. Crescimento e produtividade do almeirão em concentrações de $\mathrm{N}$ total contendo $\mathrm{NH}_{4}{ }^{+}$na solução nutritiva. Ciência Rural 37:1170-3.

Kerbiriou, P. J., T. J. Stomph, E. T. Lammerts van Bueren, and P. C. Struik. 2014. Modelling concept of lettuce breeding for nutrient efficiency. Euphytica 199:167-81.

López-Pozos, R., G. A. Martínez-Gutiérrez, R. Pérez-Pacheco, and M. Urrestarazu. 2011. The effects of slope and channel nutrient solution gap number on the yield of tomato crops by a nutrient film technique system under a warm climate. HortScience 46:727-9.

Maboko, M. M., and C. P. Du Plooy. 2009. Effect of plant spacing on growth and yield of lettuce (Lactuca sativa L.) in a soilless production system. South African Journal of Plant and Soil 26:195-7.

Mou, P., R. H. Jones, Z. Tan, Z. Bao, and H. Chen. 2013. Morphological and physiological plasticity of plant roots when nutrients are both spatially and temporally heterogeneous. Plant and Soil 364:373-84.

Novo, M. C. S. S., P. E. Trani, and K. Minami. 2003. Desempenho de três cultivares de almeirão sob cultivo protegido. Horticultura Brasileira 21:84-7.

Paulus, D., D. Dourado Neto, and E. Paulus. 2012. Análise sensorial, teores de nitrato e de nutrientes de alface cultivada em hidroponia sob águas salinas. Horticultura Brasileira 30:18-25. 
Pôrto, M. L. A., J. C. Alves, A. P. Souza, R. C. Araújo, J. A. Arruda, and U. A. Tompson Júnior. 2012. Doses de nitrogênio no acúmulo de nitrato e na produção de alface em hidroponia. Horticultura Brasileira 30:539-43.

Rasmussen, M. K., C. L. Klausen, and B. Ekstrand. 2014. Regulation of cytochrome P450 mRNA expression in primary porcine hepatocytes by selected secondary plant metabolites from chicory (Cichorium intybus L.). Food Chemistry 146:255-63.

Sakai, R. H., E. J. Ambrosano, A. C. A. Negrini, P. C. O. Trivelin, E. A. Schammass, and P. C. T. Melo. 2011. N transfer from green manures to lettuce in an intercropping cultivation system. Acta Scientiarum. Agronomy 33:679-86.

Santos, F., P. E. Trani, M. C. S. S. Novo, and F. A. Passos. 2013. Desempenho agronômico de quatro cultivares de almeirão. Horticultura Brasileira 31:153-6.

Sonneveld, C., and N. Straver. 1994. Nutrient solutions for vegetables and flower grow in water or substrates. Naaldiwijk, The Netherlands: Proefstation voor Tuinbouw onder Glas.

Steiner, F., M. C. Lana, M. M. Echer, T. Zoz, and J. F. Frandoloso. 2010. Acúmulo de nitrato e produção de duas cultivares de almeirão em função da adubação nitrogenada. Global Science And Technology 3:60-9.

Ulrich, A. 1952. Physiological bases for assessing the nutritional requirements of plants. Annual Review of Plant Physiology 3:207-28.

Urrestarazu, M., A. Postigo, M. Salas, A. Sánchez, and G. Carrasco. 1998. Nitrate accumulation reduction using chloride in the nutrient solution on lettuce growing by NFT in semiarid climate conditions. Journal of Plant Nutrition 21:1705-14.

Urrestarazu, M., M. C. Salas, D. Valera, A. Gómez, and P. C. Mazuela. 2008. Effects of heating nutrient solution on water and mineral uptake and early yield of two cucurbits under soilless culture. Journal of Plant Nutrition 31:527-38. 